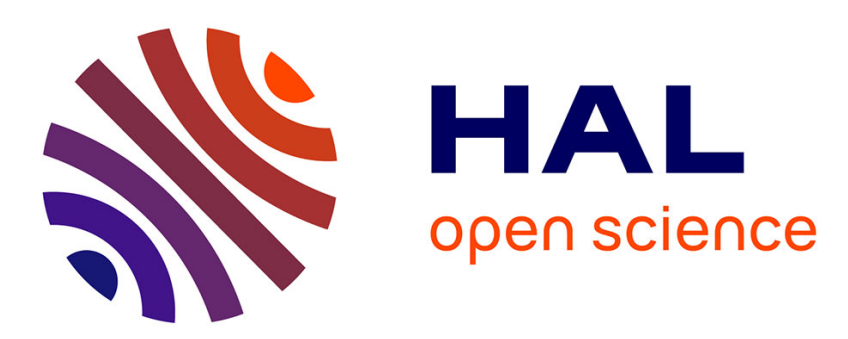

\title{
Entrepreneurial Motivation and Business Performance: Evidence from a French Microfinance Institution
}

\author{
Renaud Bourlès, Anastasia Cozarenco
}

\section{To cite this version:}

Renaud Bourlès, Anastasia Cozarenco. Entrepreneurial Motivation and Business Performance: Evidence from a French Microfinance Institution. Small Business Economics, 2018, 51 (4), pp.943-963. 10.1007/s11187-017-9961-8 . halshs-01954474

\section{HAL Id: halshs-01954474 \\ https://shs.hal.science/halshs-01954474}

Submitted on 8 Apr 2019

HAL is a multi-disciplinary open access archive for the deposit and dissemination of scientific research documents, whether they are published or not. The documents may come from teaching and research institutions in France or abroad, or from public or private research centers.
L'archive ouverte pluridisciplinaire HAL, est destinée au dépôt et à la diffusion de documents scientifiques de niveau recherche, publiés ou non, émanant des établissements d'enseignement et de recherche français ou étrangers, des laboratoires publics ou privés. 


\title{
Entrepreneurial motivation and business performance: evidence from a French Microfinance Institution
}

\author{
Renaud Bourlès (i) • Anastasia Cozarenco
}

\begin{abstract}
This article examines the link between entrepreneurial motivation and business performance in the French microfinance context. Using handcollected data on business microcredits from a Microfinance Institution (MFI), we provide an indirect measure of entrepreneurial success through loan repayment performance. Controlling for the endogeneity of entrepreneurial motivation in a bivariate probit model, we find that "necessity entrepreneurs" are more likely to have difficulty repaying their microcredits than "opportunity entrepreneurs". However, type of motivation does not appear to make a difference to business survival. We test for the robustness of our results using parametric duration models and show that necessity entrepreneurs experience difficulties in loan repayment earlier than their opportunity counterparts, corroborating our initial findings. Our results are also robust to a sharper analysis of motivation, focusing
\end{abstract}

\footnotetext{
R. Bourlès $(\bowtie)$

Aix-Marseille Université, CNRS, EHESS, Centrale Marseille, AMSE, 38 rue Frédéric Joliot-Curie, 13451

Marseille Cedex 20, France

e-mail: renaud.bourles@centrale-marseille.fr

A. Cozarenco

Montpellier Business School, Montpellier Research in Management, and Centre for European Research in Microfinance (CERMi), 2300, Avenue des Moulins, 34185 Montpellier Cedex 4, France

e-mail: a.cozarenco@montpellier-bs.com
}

on unemployment (on the necessity side) and nonpecuniary benefits from success (on the opportunity side).

Keywords Opportunity and necessity entrepreneurs · Business microcredit · Loan repayment $\cdot$ Business survival

JEL Classification $\mathrm{C} 30 \cdot \mathrm{C} 41 \cdot \mathrm{G} 21 \cdot \mathrm{L} 26 \cdot \mathrm{M} 13$

\section{Introduction}

The microcredit is an innovative way to address financial and social exclusion. Microcredits are particularly small loans to poor individuals who cannot easily access mainstream financial markets. We distinguish between two main categories of microcredit, business and personal loans. ${ }^{1}$ Business microcredits are intended for business start-up and development, to foster self-employment. Personal loans target personal and family development projects. In this paper, we use a hand-collected data set on business microcredits from a French Microfinance Institution (MFI) to study the relationship between entrepreneurial motivation and business performance, in terms of loan repayment and business survival.

\footnotetext{
${ }^{1}$ Sometimes, microfinance institutions do not differentiate between two types of products, since the boundary between the business and the household is not clearly drawn.
} 
It is widely recognized that entrepreneurship generates economic growth (Reynolds et al. 2005; Audretsch and Thurik 2001). In the European Union in 2012, almost $93 \%$ of all businesses were microenterprises (employing fewer than 10 people). Microenterprises made the second highest contribution in terms of employment and value added, after large firms (employing more than 250 people) (Eurostat 2015).

Considerable research effort has been directed toward identifying the determinants of entrepreneurial performance. One important aspect of this research is distinguishing among different typologies of entrepreneurs (Wennekers and Thurik 1999). Entrepreneurial typologies can, for instance, be defined according to owners' motivation. Since 2001, the Global Entrepreneurship Monitor (GEM) distinguishes between two different types of entrepreneurial motivation, translating into necessity and opportunity entrepreneurship. According to the GEM survey, in 2016 three-quarter of entrepreneurs report opportunistic motivation, while one-quarter say they are acting out of necessity. However, there is great heterogeneity across countries, with developed countries having a larger proportion of opportunity entrepreneurs (Reynolds et al. 2005).

Distinguishing between these two types is important, both from theoretical and practical standpoints (Block and Wagner 2010). Opportunity entrepreneurs start a business voluntarily, to take advantage of new opportunities (Kirkwood 2009), for more independence or self-fulfillment (Taylor 1996; Dalborg and Wincent 2015). In contrast, necessity entrepreneurs get involved in a business because they have difficulties remaining in the paid job market (Gilad and Levine 1986; Bergmann and Sternberg 2007). They can be described as requirement-based (Block and Sandner 2009) or against-their-will (Korunka et al. 2003) entrepreneurs. According to the existing literature, there are significant differences between the two types of entrepreneurs. First, in terms of individual characteristics, necessity entrepreneurs are generally older (Wagner 2005; Bhola et al. 2006; Block and Sandner 2009; Block and Wagner 2010), either less (Bhola et al. 2006) or equally (Block and Sandner 2009) educated and less likely to have a parent involved in entrepreneurship (Wagner 2005; Bhola et al. 2006).

Recently, literature has tried to go beyond this dichotomy. The last GEM report in 2016 defines improvement-driven-opportunity (IDO) entrepreneurs as those seeking to improve their situation regarding independence or income. It reports four times more IDO than necessity entrepreneurs in the more advanced economies. Stephan et al. (2015) distinguish among four types of motivation: autonomy, challenge, family-related, and financial. They find that businesses driven by autonomy or family-related motivation are more likely to survive. We follow this new strand of literature by looking more deeply into the effect of unemployment (on the necessity side) and non-pecuniary benefits from success (on the opportunity side).

There are different ways to assess entrepreneurial performance. Existing studies have mainly focused on such measures of performance as business survival, employment or turnover growth. Using growth as a sign of performance is particularly tricky, since a meaningful proportion of entrepreneurs choose not to grow (Jaouen and Lasch 2015). But many micro startups require access to credit to get going. ${ }^{2}$ Therefore, loan repayment is a reasonable alternative measure of business performance, that is not affected by individual choice not to grow. Interestingly, to the best of our knowledge, none of the existing studies have focused on the loan repayment performance of different types of micro-entrepreneurs. We fill this gap by investigating whether necessity entrepreneurs are different from their opportunity counterparts in terms of loan repayment. To link our findings with the existing literature, we will perform parallel business survival analysis, exploring whether necessity entrepreneurs are more likely than opportunity entrepreneurs to close their businesses, as some previous studies suggest (Millán et al. 2012; Oberschachtsiek 2012; Andersson and Wadensjo 2007), or whether there is no significant difference between them (Block and Sandner 2009).

Microfinance is a new and relatively underresearched domain in the entrepreneurship literature (Newman et al. 2014). Despite strong enthusiasm among the proponents of the microcredit, the evidence regarding its impact has so far been mixed

\footnotetext{
${ }^{2}$ In France in the first semester of 2002, almost $36 \%$ of all business start-ups were (partly) financed by commercial bank loans (source: authors' own computations using data from the French National Institute of Statistics and Economic Studies). Furthermore, commercial banks are the main providers of small-business finance, according to Berger and Udell (2002).
} 
(Armendáriz and Morduch 2010). Findings from a number of rigorous studies based on randomized controlled trials on the statistical impact of the microcredit are inconclusive (Banerjee et al. 2015). However, Newman et al. (2014), performing a qualitative study, argue that microcredits can generate sound entrepreneurial activity and improved business outcomes. As suggested by Esther Duflo, the microfinance industry now needs to distinguish between necessity and opportunity entrepreneurs, in order to provide them with appropriate services (Duflo 2010).

The literature on microfinance in Europe is scarce, mainly because the industry is relatively young and there is not yet a clear distinction between microcredits and other types of loans (European Commission 2012). Moreover, MFIs in Europe serve a niche market. $^{3}$ The major financial product is the microcredit, with a special focus on the business microcredit. ${ }^{4}$ According to Bendig et al. (2012), the five main goals of MFIs in Europe are job creation, promotion of micro- and small enterprises, financial and social inclusion and, to a lesser extent, the empowerment of particular target groups (women, migrants, etc.).

Therefore, microfinance is often viewed in Europe as a social policy aimed at encouraging selfemployment as a way out of unemployment ("push" reasons). In particular, poor individuals facing lowpaid employment are more likely to start a business out of necessity, to meet basic human needs (Naudé 2010). Jaouen and Lasch (2015) argue that the subsistence type of entrepreneur is specific to micro-firms, the main target of MFIs. At the same time, traditional banks are reluctant to finance micro-entrepreneurs willing to start a business for "pull" reasons but lacking any initial capital or credit history. These riskier projects are typical of MFI clients. Consequently, using a data set from an MFI to study entrepreneurial motivation is particularly relevant. We expect our data

\footnotetext{
${ }^{3}$ Reed et al. (2014) report that MFIs in the industrialized world represent $4.4 \%$ of total MFIs reporting to the Microcredit Summit Campaign, serving less then $3 \%$ of microfinance clients.

${ }^{4}$ The European Commission defines the microcredit as a loan of up to EUR 25,000 tailored for micro-enterprises employing less than 10 people ( $91 \%$ of all European firms), and unemployed or inactive people who want to go into self-employment but do not have access to traditional banking services.
}

set to be balanced in terms of the proportions of necessity and opportunity entrepreneurs. ${ }^{5}$

The European Union subsidizes business microcredit, seen as a stimulus to entrepreneurial initiatives that will combat unemployment. This is not surprising, since subsidies are crucial for MFIs, especially during their start-up phase (Hudon and Traça 2011). Historically, even major MFIs in developing countries have widely benefited from direct or indirect subsidies (see Morduch (1999) for the Grameen Bank case). Moreover, lack of subsidies can result in socially harmful trade-offs (D'Espallier et al. 2013). ${ }^{6}$

In France, where the state actively promotes entrepreneurship as a way out of unemployment, microfinance is perceived as a valuable tool. As most of the European MFIs, French MFIs are subsidized. These subsidies often take the form of loan guarantees (Bourlès and Cozarenco 2014). ${ }^{7}$ In this context, studying the performance of MFI clients is crucial in terms of policy implications. Block and Sandner (2009) contest the suggestion that necessity entrepreneurs are less desirable from an economic standpoint, as in Acs and Varga (2005) for instance. Insofar as they do not exhibit unequal survival rates, Millán et al. (2012) and Block and Sandner (2009) argue that public support to initially unemployed or necessity entrepreneurs is justified. However, these studies do not look at the quality of the surviving businesses. In this paper, we use an indirect strategy to infer business success through the loan repayment behavior of micro-borrowers from a French MFI. This paper is novel in addressing the link between entrepreneurial motivation and performance in the microfinance context.

The rest of the paper proceeds as follows. In the next section, we sketch the theoretical mechanisms linking entrepreneurial motivation and business performance and formulate the empirical hypotheses to

\footnotetext{
${ }^{5}$ Kariv and Coleman (2015) show that both types of entrepreneurs are likely to request small loans.

${ }^{6}$ Still, the abundance of subsidies may explain the scarcity of complementary financial products such as microsavings (Cozarenco et al. 2016).

${ }^{7}$ At the European level, the European Investment Fund offers guarantees to microfinance providers through the Employment and Social Innovation (EaSI) Guarantee Instrument. The guarantee rate is up to $80 \%$. At the national level, France Active Guarantee (FAG) offers guarantees up to $70 \%$ of the amount of business microcredits and Fonds de Cohésion Sociale and Caritas up to $50 \%$ of the amount of personal microcredits. For all these initiatives, cap loss rates apply.
} 
be tested. In Section 3, our data set and the descriptive statistics are introduced. In Section 4, we present the econometric model and results. We study an alternative measure of business performance based on duration models in Section 5. Finally, we discuss policy implications and conclude.

\section{Theoretical framework and hypotheses}

In this section, we analyze the link between entrepreneurial motivation and business performance from a theoretical point of view. To do so, we first examine the key differences between necessity and opportunity entrepreneurs. We argue that these differences mainly lie in the non-pecuniary benefits from entrepreneurship and external (employment) opportunities (i.e., the opportunity cost of entrepreneurship), leading to an ambiguous effect of entrepreneurial motivation on business performance.

Several empirical papers point out the nonpecuniary benefits from entrepreneurship (or selfemployment). Hamilton (2000) notably shows that the difference in earnings between employed and selfemployed individuals cannot be explained by selfselection. In the same vein, Benz and Frey (2008) show that pay (or material) differences cannot fully explain the discrepancies in job satisfaction between the two groups (this was also highlighted by Blanchflower 2000).

These non-pecuniary benefits seem to be linked to independence, autonomy, or skill utilization (see Taylor 1996; Hundley 2001; Benz and Frey 2008; Lange 2012). ${ }^{8}$ From a theoretical point of view, such benefits can be related to the concept of intrinsic motivation introduced by Benabou and Tirole (2003). From our perspective, in line with the above discussion, these non-pecuniary benefits should be rather limited for necessity entrepreneurs, who are by definition mainly driven by monetary motives. At least, they should be stronger for opportunity entrepreneurs, for whom entrepreneurship is clearly a choice.

This difference is expected to lead to better performance for opportunity entrepreneurs. However, this has to be balanced with the fact that they also enjoy better external opportunities. As previously pointed

\footnotetext{
${ }^{8}$ It can also be linked to the notion of passion, which may be related to entrepreneurial motivation (Dalborg and Wincent 2015).
}

out, opportunity entrepreneurs appear to be better educated (Bhola et al. 2006) and also to benefit from better (or more) alternative employment opportunities (Bergmann and Sternberg 2007). As a result, businesses founded by opportunity entrepreneurs could close earlier, as they might be offered better job opportunities or expect higher returns for remaining in business.

Therefore, on the one hand, businesses run by opportunity entrepreneurs should perform better because of higher (intrinsic) motivation; but, on the other hand, they could close more often because of higher opportunity cost of entrepreneurship. ${ }^{9}$

However, the negative effect of external opportunity on business survival should not necessarily translate into lower loan repayment. Indeed, in case of business closure due to a better outside option, entrepreneurs are likely to continue repaying their loans, to maintain a good credit history. Therefore, the negative effect of external opportunity should be greater on business survival than on credit repayment. ${ }^{10}$ This leads us to formulate two complementary hypotheses regarding our two measures of business performance.

\section{Hypothesis 1 Necessity (or employment-driven) entrepreneurs uncover more difficulties in repaying their loans.}

Hypothesis 2 The effect of entrepreneurial motivation is stronger on loan repayment than on business survival.

If any, the effect of entrepreneurial motivation on loan repayment might also be due to less preparation for venture launching (Block et al. 2015). ${ }^{11}$ In this

\footnotetext{
${ }^{9}$ To that extent, the theoretical predictions concerning the link between entrepreneurial motivation and business performance seem to be ambiguous. We formalize this argument in the working paper version of this paper (Bourlès and Cozarenco 2017), in which we adapt the canonical model of Tirole (2006) to account for microcredit specificity and differences between necessity and opportunity entrepreneurs. We show that the probability of success of a business increases in the entrepreneurs' non-pecuniary benefit from success and decreases in their external opportunity. This result suggests an ambiguous effect of entrepreneurial motivation on business survival.

${ }^{10}$ This can moreover be combined with bootstrapping by the necessity entrepreneurs (Jonsson and Lindbergh 2013).

${ }^{11}$ We thank an anonymous referee for pointing out this issue.
} 


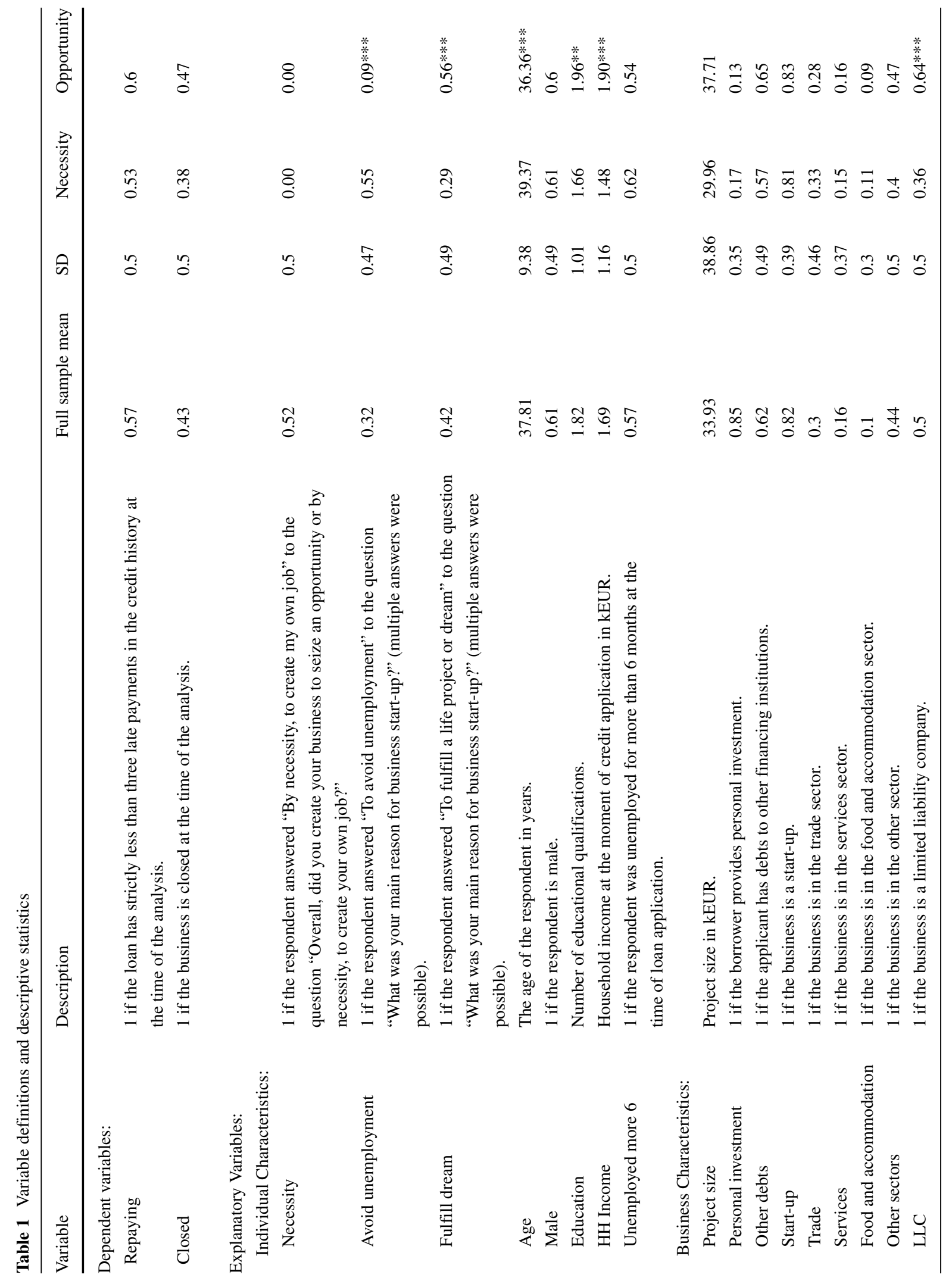




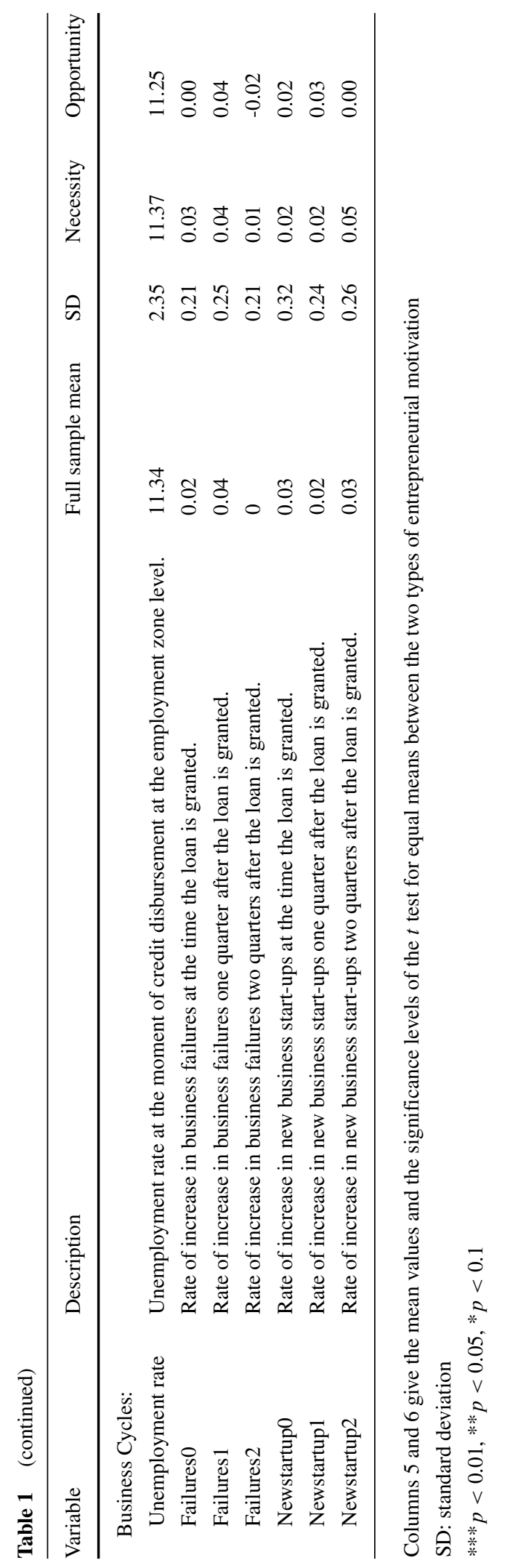

case, the differences in loan repayment would be concentrated at the beginning of the credit history. This forms our third hypothesis.

Hypothesis 3 If the disparities between opportunity and necessity entrepreneurs are mostly due to differences in business project preparation, the effect of entrepreneurial motivation on loan repayment should decrease along the credit history.

We test these hypotheses using a bivariate probit model in Section 4 and check the robustness of our results using duration models in Section 5.

\section{Methodology}

\subsection{Institutional background and data}

Our sample contains micro-firms started by the clients of a French MFI, created in 2006 and operating in the Provence-Alpes-Côte-d'Azur (PACA) region as a non-profit non-governmental organization (NGO). It was created at the initiative of a commercial bank under its corporate social responsibility policy. Its target clients are individuals who have difficulty accessing credit from mainstream banks. The MFI does not require any collateral or guarantees from its clients. Each entrepreneur can apply only once for a microcredit. The MFI aims for financial inclusion of all borrowers after granting the first microcredit. ${ }^{12}$ It operates in collaboration with public organizations which provide business development services and follow-up at different stages. We focus exclusively on business microcredits in our analysis.

Most of the MFI's clients are (long-term) unemployed, have low education and income levels, and are starting a business for the first time. Many of the clients are becoming self-employed to avoid unemployment and/or poverty. Therefore, we expect to observe a relatively large proportion of necessity entrepreneurs in our sample compared to previous studies (see Block and Sandner 2009, Table 6 for studies in the German context where necessity entrepreneurs represent between 6.7 and $45.5 \%$ ). In this context, it is particularly relevant to investigate

\footnotetext{
${ }^{12}$ As a consequence, the MFI does not provide dynamic incentives through progressive lending (Armendáriz and Morduch 2010).
} 
the performance of both types of entrepreneurs (necessity and opportunity) in terms of loan repayment and business survival.

We provide the descriptive statistics (for the full sample and for the sample split by entrepreneurial motivation) of all the variables used in the analysis in Table 1. The average loan granted in our sample is EUR 8250 (median loan size is EUR 7000). The average project size is kEUR 33.93 which is large for a new venture by any standards (opportunity entrepreneurs undertake larger projects than necessity entrepreneurs). The median project size is kEUR 20.68 , suggesting that the distribution of project size is highly right skewed compared to the loans' size. This might be due to the specificity of the French regulation which capes microcredits offered by licensed MFIs at EUR 10,000.

The difference between the project size and the microcredit size is generally financed through cofinancing schemes with traditional banks (Cozarenco and Szafarz 2016), honor loans ${ }^{13}$ or personal investment. It is worth reminding that micro-borrowers are underserved by traditional banks, mostly because of informational asymmetries due to the lack of collateral or credit history. MFIs mitigate informational asymmetries through their lending technology based on closer monitoring and follow-up (Armendáriz and Morduch 2000). This gives rise to partnerships between banks and MFIs (Cozarenco 2015). Cofinancing is one type of these partnerships and is profitable both for the bank and the MFI (Cozarenco and Szafarz 2016).

The average duration of a microcredit is $\mathbf{5 2}$ months (repayments take place monthly) and the average annual interest rate is $4.4 \%$. The interest rate is fixed by the MFI and does not vary according to personal or project characteristics, which is a specific feature of microfinance worldwide. These figures are in line with the overall French microfinance industry. The European Microfinance Network reports an average business microcredit duration of 48 months (seven responding MFIs) and an average annual interest rate of $4.5 \%$ (four responding MFIs). This duration is mainly explained by the (quasi)absence of progressive lending in France. Micro-borrowers are generally expected to graduate to traditional banking after

\footnotetext{
${ }^{13}$ The so-called honor loans are subsidized personal loans granted by the French government to start or buy out a business. Their size varies between EUR 2000 and 50,000.
}

their first microcredit. Similarly, the low interest rate reflects a highly social orientation of MFIs in France, and could partially be explained by the presence of direct and indirect subsidies.

Our data set is built using several sources. It includes five different types of information:

1. Individual and business characteristics.

2. Repayment history within the MFI.

3. Business survival status and date of closure when applicable.

4. Information on entrepreneurial motivation.

5. Data on business cycles at PACA-region level by sector of activity and unemployment rates at the employment zone level.

Individual and business characteristics and repayment history were provided directly by the MFI. Information on repayment histories was last updated in January 2016.

Information on business survival was collected and updated in March 2016 from the French website www.societe.com, containing general information about both closed and active French firms. Interestingly, the 3-year survival rate in our sample is $83 \%$, whereas it is $68 \%$ for the PACA region, according to national statistics. ${ }^{14}$ Similarly, the 5-year survival rate is higher in our sample (66 versus $55 \%$ for PACA region).

Further, to differentiate between types of entrepreneur (necessity or opportunity), we conducted a survey among the clients of the MFI. Of the 574 granted loans (between April 2008 and April 2012), 294 micro-entrepreneurs agreed to participate in the survey, a $51 \%$ response rate. A combination of web (20\% of respondents) and telephone (80\% of respondents) survey methods were used to collect data on entrepreneurial motivation between July 1st 2012 and September 15, 2012.

To distinguish necessity from opportunity entrepreneurs, we asked participants the following question "Overall, did you create your business to seize an opportunity, or by necessity, to create your own job?". Ninety-five percent of respondents could classify themselves in one of the two categories. This trend is consistent with survey data from GEM (Reynolds et al. 2005). One hundred forty-three

\footnotetext{
${ }^{14}$ The 3-year survival rate for businesses created in 2010 in PACA region. Source: the French National Institute of Statistics and Economic Studies website, accessed on June 14, 2016.
} 
(49\%) replied that they had started their business by necessity, to create their own job. We term these respondents necessity entrepreneurs. One hundred thirty-four $(46 \%)$ declared that they had started a business to seize an opportunity. We term these respondents opportunity entrepreneurs. Finally, 17 (5\%) declared both types of motivation. We exclude these $5 \%$ of respondents from our analysis, since their motivations are not clearly differentiated. Unsurprisingly, the proportion of necessity entrepreneurs among the respondents in our data set is considerably larger than in existing studies. As mentioned before, this bias toward necessity entrepreneurship in our data set is useful for comparison, and is explained by the context of microfinance in France. The microcredit is viewed here as a tool for public policy encouraging selfemployment, especially for unemployed individuals.

Finally, the data on business cycles and unemployment rates was collected from the French National Institute of Statistics and Economic Studies (INSEE).

\subsection{Dependent variables}

The dependent variables in our analysis represent different measures of entrepreneurial success. In our baseline model, we use two main measures of performance. The first dependent variable, Repaying, is a dummy taking value one if a client has strictly less than three late payments in his or her credit history as of January 2016. These late payments can be either outstanding or repaid at the time of analysis. This definition is close to that used by the MFI for written-off loans, corresponding to loans with three or more consecutive late payments. We do not focus exclusively on consecutive late payments, since it is not our aim to capture exclusively written-off loans. Our aim is to capture problematic borrowers, who have difficulty paying their debts. Fifty-seven percent of our sample had less than three late payments in their credit history at the time of the analysis. The difference between necessity and opportunity entrepreneurs is a priori non-significant in that respect.

The second performance measure is the dummy variable Closed, taking value one if the business is closed as of March 2016. Forty-three percent of businesses in our sample closed during the observation period. As for the first performance measure, descriptive statistics do not reveal any differences regarding entrepreneurial motivation.

\subsection{Explanatory variables}

The main explanatory variable is the Necessity dummy (see Table 1 for definition). As expected, more than $50 \%$ of our sample identify themselves as necessity entrepreneurs. The second most important variable, which we use as an instrument (see next section), is Avoid_unemployment. It is a dummy variable taking value one if respondents answered "To avoid unemployment" to the question "What was your main reason for business start-up?", multiple answers being possible. Other possible answers to this question include the following: to fulfill a life project or dream, to increase personal revenue, to have more independence, to benefit from subsidies for business start-up, or others. Interestingly, only $32 \%$ of respondents answered Avoid_unemployment to this question, meaning that not all necessity entrepreneurs take up self-employment in order to avoid unemployment. Still, as expected, it entails a considerable difference between the two types of entrepreneurs: $55 \%$ of necessity entrepreneurs stated to have started a business to avoid unemployment, against only $9 \%$ of opportunity entrepreneurs.

To go beyond the necessity-opportunity dichotomy, we also analyze the impact of answering "to fulfill a life project or dream" to this question. We then define the dummy Fulfill_dream (taking value one if respondents answered "to fulfill a life project or dream") that proxies the notion of non-pecuniary benefits discussed in the previous section. Forty-two percent of the respondents stated that they have started a business in order to fulfill a life project or dream. As expected, the difference is statistically significant between necessity and opportunity entrepreneurs. However, the gap ( $29 \%$ for necessity entrepreneurs and $56 \%$ for opportunity entrepreneurs) is sensitively smaller than for the Avoid_unemployment dummy. These descriptive statistics illustrate the complexity of the definition of entrepreneurial motivation and appeal for going beyond this dichotomy. ${ }^{15}$

Other control variables include age, the square of age, ${ }^{16}$ gender, education level, household income, a dummy variable for long-term unemployment, size of

\footnotetext{
${ }^{15}$ We thank an anonymous referee for pointing out this issue.

${ }^{16}$ Taylor (1996) suggests a non-linear effect of age on selfemployed earnings.
} 
the project, having other debts, start-up, activity sectors, and limited liability company dummies. Most of the respondents are start-ups. This is consistent with Shahriar et al. (2016) who argue that not-for-profit MFIs are more likely to finance business start-ups than for-profit ones.

According to Millán et al. (2012), the inclusion of "macroeconomic sources of variance" considerably improves the quality of outcomes attributable to individual effects. Hence, we additionally control for quarterly rates of increase in business failures (as a measure of economic health) and in new business start-ups (as a measure of competition) at the time the loan is granted (as well as one and two quarters later) for each micro-enterprise in our sample, according to its sector of activity. Data for business cycles exclusively cover the French PACA Region, the region where the MFI providing data operates (Source: INSEE). In line with Taylor (1996), we also control for the unemployment rate in borrower's employment zone (which roughly corresponds to the town or the city of residence) at the moment of credit disbursement (source: INSEE).

See Table 1 for the definitions of all the variables used in our empirical analysis. Finally, to explore the differences between opportunity and necessity entrepreneurs, we present the results of a simple probit regression in Table 2, where the dependent variable is the dummy Necessity. We find that necessity entrepreneurs are more likely to take up selfemployment in order to avoid unemployment, tend to be older and come from poorer households. These findings are in line with Block and Sandner (2009). We also reveal that necessity entrepreneurs are less likely to set up limited liability companies, meaning that they are more likely to set up sole proprietorships.

\section{Model estimation and results}

In this paper, we are interested in the effect of entrepreneurial motivation on repayment performance and business survival. As explained in the previous section, the main explanatory variable here is Necessity. However, this variable can be endogenously determined. For instance, ex-ante necessity entrepreneurs can shift to opportunity status over time. Jayawarna et al. (2013) argue that entrepreneurial motivation is not static and is influenced by career,
Table 2 Determinants of entrepreneurial motivation

\begin{tabular}{|c|c|c|}
\hline & \multicolumn{2}{|c|}{$\begin{array}{l}\text { Dependent variable: } \\
\text { necessity dummy }\end{array}$} \\
\hline \multicolumn{3}{|l|}{ Explanatory variables: } \\
\hline Avoid unemployment & $1.57 * * *$ & $(0.21)$ \\
\hline Age & $0.15^{*}$ & $(0.08)$ \\
\hline $\mathrm{Age}^{2}$ & $-0.002^{*}$ & $(0.001)$ \\
\hline Male & 0.22 & $(0.20)$ \\
\hline Education & -0.00 & $(0.10)$ \\
\hline $\mathrm{HH}$ income & $-0.21 * *$ & $(0.08)$ \\
\hline Unemployed more 6 & -0.17 & $(0.19)$ \\
\hline Project size & -0.00 & $(0.00)$ \\
\hline Personal investment & 0.01 & $(0.27)$ \\
\hline Other debts & -0.14 & $(0.19)$ \\
\hline Start-up & 0.04 & $(0.26)$ \\
\hline Trade & 0.34 & $(0.23)$ \\
\hline Services & 0.06 & $(0.27)$ \\
\hline Food and accommodation & 0.22 & $(0.33)$ \\
\hline LLC & $-0.67 * * *$ & $(0.20)$ \\
\hline Unemployment rate & 0.01 & $(0.04)$ \\
\hline Constant & $-3.10^{*}$ & $(1.60)$ \\
\hline Observations & 275 & \\
\hline
\end{tabular}

Standard errors in parentheses

$* * * p<0.01, * * p<0.05, * p<0.1$

household and business life. In our case, this dynamic aspect of motivation is particularly important, since we do not observe motivation at the time of business start-up. Instead, we observe entrepreneurial motivation at the time of the survey, which corresponds to different stages in the life of the businesses, ranging from start-ups to well-established firms. Econometrically, the unobserved changes in individual lifecourses correspond to the problem of omitted variables. To deal with this caveat, we use a bivariate probit model appropriate to binary endogenous variables (see Wooldridge 2010, pp. 594-599). ${ }^{17}$ Using a simple probit equation which does not account for the endogeneity of the Necessity dummy would lead to inconclusive results (Block et al. 2011). The instrument we use to correct for the endogeneity of the Necessity variable is the dummy variable Avoid_unemployment. This variable does not have

\footnotetext{
${ }^{17}$ Mimicking a two-step procedure would not lead to consistent parameter estimations, according to Wooldridge (2010).
} 
the dynamic nature highlighted by Jayawarna et al. (2013).

Our bivariate probit model writes as follows:

$y_{i}=\mathbb{1}\left[\alpha_{i}\right.$ Necessity $\left.+\boldsymbol{z}_{\mathbf{1}} \boldsymbol{\beta}_{\mathbf{1 i}}+e_{1 i}\right]$

Necessity $=\mathbb{1}\left[\boldsymbol{z} \boldsymbol{\beta}_{\mathbf{2}}+e_{2}\right]$

where $\left(e_{1 i}, e_{2}\right)$ are independent of $z$ and distributed as bivariate normal with mean zero, unit variance, and $\rho_{i}=\operatorname{Corr}\left(e_{1 i}, e_{2}\right)$. If $\rho_{i} \neq 0$, then estimating Eq. 1 using a simple probit model would not lead to consistent estimators of parameters $\alpha_{i}$ and $\boldsymbol{\beta}_{\mathbf{1 i}}$. We will use the LR test to test the null hypothesis $\rho_{i}=0$. This is appropriate to test for exogeneity of binary variables, as suggested by Wooldridge (2010). Variable $y_{i}$ is the dependent variable, representing the performance of the entrepreneur, with $i \in$ $\{$ Repaying, Closed $\}$. As mentioned before, we use two measures of entrepreneurial performance, the first being the dummy variable Repaying and the second being the dummy variable Closed.

The vector $z_{1}$ includes the constant term and all the explanatory variables defined in Table 1, except the variable Avoid_unemployment. The latter is used as an instrument in our model and is only included in vector $z$, which also includes vector $z_{1}$.

Our data will support Hypothesis 1-that necessity entrepreneurs uncover more difficulties in repaying their loans-if $\alpha_{\text {Repaying }}<0$. Similarly, hypothesis 2-that the effect of entrepreneurial motivation is stronger on loan repayment than on business survival-will be supported if $\alpha_{\text {Repaying }}<\alpha_{\text {Closed }}$.

We moreover test Hypothesis 3-according to which disparities between necessity and opportunity entrepreneurs are mainly due to the lack of business project preparation-by re-estimating our model for $y_{\text {Repaying }}$ after excluding observations with at least three late payments along the first 24 months of the loan history (we exclude observations gradually every 3 months). Our results will support Hypothesis 3 if the marginal effects of the Necessity dummy decrease (in absolute value) or become insignificant when early repayment issues are ignored.

We present the results of the estimation of the bivariate probit model in Table 3. Columns (1) and (2) report the results for loan repayment estimations and columns (3) and (4) report the results for business survival. Business cycles are included in columns (2) and (4).
In terms of loan repayment, we find a negative effect of necessity motivation on the likelihood of having less than three late payments $\left(\alpha_{\text {Repaying }}<0\right)$. This result suggests that necessity entrepreneurs are significantly more likely to have difficulty with loan repayment. Hypothesis 1 is thus supported by our regression results. While our paper is innovative in exploiting the relationship between entrepreneurial motivation and loan repayment, this result corroborates previous studies finding that necessity entrepreneurs undertake less profitable projects (Block and Wagner 2010) or are unwilling to grow (Jaouen and Lasch 2015). This result is also in line with Andersson and Wadensjo (2007), who find that initially unemployed or inactive entrepreneurs earn lower incomes than entrepreneurs who were initially wage-earners.

In terms of business survival, we find a nonsignificant effect of necessity motivation on business survival, supporting Hypothesis 2. This result is in line with Block and Sandner (2009). While opportunity entrepreneurs perform better, enjoying greater intrinsic benefits from running a business, this positive effect on effort is counterbalanced by greater external opportunities. These opportunities may lead to them closing their business despite better financial performance. The coexistence of these two effects may explain the non-significant effect of entrepreneurial motivation on business survival.

Concerning the control variables, we note that loan repayment and business survival are not impacted by exactly the same set of determinants. We find that older borrowers are more likely to successfully manage their loan repayment, ${ }^{18}$ but no effect of age on business closure.

Gender does not significantly impact loan repayment or business survival. The literature does not reach consensus on this relationship. Our insignificant effect is in line with Oberschachtsiek (2012), while others find a negative impact of the male dummy on business closure (Millán et al. 2012) or repayment (D'Espallier et al. 2013).

We find a non-significant effect of education on loan repayment. In contrast, there is a significantly negative relationship between education and business closure. This is in line with Millán et al. (2012) and Bates (1990). The latter study reveals that businesses

\footnotetext{
${ }^{18}$ Given the non-linear relationship, the effect would become negative for individuals older than 80 years old. However, we do not have such observations in our data set.
} 
Table 3 Determinants of entrepreneurial performance

Dependent variable:

Repaying

(1)
Closed

(3)

(4)

\begin{tabular}{lllllllll}
\hline Explanatory variables: & & & & & & & & \\
Necessity & $-0.91^{* * *}$ & $(0.32)$ & $-0.98^{* * *}$ & $(0.35)$ & 0.13 & $(0.37)$ & 0.05 & $(0.37)$ \\
Age & $0.24^{* * *}$ & $(0.07)$ & $0.24^{* * *}$ & $(0.07)$ & 0.01 & $(0.08)$ & 0.01 & $(0.08)$ \\
Age $^{2}$ & $-0.003^{* * *}$ & $(0.001)$ & $-0.003^{* * *}$ & $(0.001)$ & -0.00 & $(0.00)$ & -0.00 & $(0.00)$ \\
Male & -0.20 & $(0.18)$ & -0.16 & $(0.18)$ & -0.24 & $(0.18)$ & -0.25 & $(0.19)$ \\
Education & 0.07 & $(0.09)$ & 0.10 & $(0.09)$ & $-0.22^{* *}$ & $(0.09)$ & $-0.22^{* *}$ & $(0.09)$ \\
HH income & -0.04 & $(0.07)$ & -0.04 & $(0.08)$ & 0.05 & $(0.08)$ & 0.06 & $(0.08)$ \\
Unemployed more 6 & -0.06 & $(0.16)$ & -0.03 & $(0.17)$ & 0.11 & $(0.17)$ & 0.11 & $(0.17)$ \\
Project size & -0.00 & $(0.00)$ & -0.00 & $(0.00)$ & -0.00 & $(0.00)$ & -0.00 & $(0.00)$ \\
Personal investment & 0.30 & $(0.24)$ & 0.36 & $(0.25)$ & -0.34 & $(0.24)$ & -0.28 & $(0.25)$ \\
Other debts & 0.21 & $(0.17)$ & $0.34 *$ & $(0.18)$ & $-0.38^{* *}$ & $(0.17)$ & $-0.31^{*}$ & $(0.18)$ \\
Start-up & -0.12 & $(0.22)$ & -0.19 & $(0.23)$ & $0.41^{*}$ & $(0.24)$ & $0.40^{*}$ & $(0.24)$ \\
Trade & 0.08 & $(0.20)$ & 0.09 & $(0.21)$ & $0.41^{* *}$ & $(0.21)$ & $0.42^{* *}$ & $(0.21)$ \\
Services & 0.30 & $(0.25)$ & 0.29 & $(0.25)$ & -0.29 & $(0.26)$ & -0.32 & $(0.26)$ \\
Food and accommodation & -0.27 & $(0.28)$ & -0.35 & $(0.29)$ & $0.67 * *$ & $(0.29)$ & $0.66^{* *}$ & $(0.30)$ \\
LLC & -0.08 & $(0.20)$ & -0.10 & $(0.20)$ & -0.04 & $(0.21)$ & -0.07 & $(0.21)$ \\
$\rho$ & $0.61^{* *}$ & $(0.22)$ & $0.62^{*}$ & $(0.24)$ & 0.05 & $(0.24)$ & 0.08 & $(0.24)$ \\
Constant & $-4.32^{* * *}$ & $(1.47)$ & $-4.69^{* * *}$ & $(1.53)$ & 0.65 & $(1.49)$ & 0.50 & $(1.53)$ \\
Business cycles & No & & Yes & & No & & Yes & \\
Observations & 275 & & 275 & & 275 & & 275 & \\
\hline
\end{tabular}

Standard errors in parentheses

$* * * p<0.01, * * p<0.05, * p<0.1$

started by highly educated owners are more likely to be viable and long-lasting than those started by less educated owners.

We find no significant relationship between household income and loan repayment and business survival. The literature mainly supports a positive relationship between initial wealth and business survival, although insignificant results are also reported.

We find that the size of the project has no significant impact, in contrast to Oberschachtsiek (2012). However, that author uses a dummy variable to distinguish between businesses larger than EUR 25,000, whereas we use a continuous variable.

Interestingly, having other debts from financing institutions improves loan repayment performance (the effect is significant at $10 \%$ in column (2)) and business survival. It is important to mention that the MFI will only disburse funds if all other co-financing parties agree to finance the client. Therefore, the effect is probably due to the screening complementarities between the MFI and other financing institutions, which can be commercial banks or other public partners (Cozarenco and Szafarz 2016). ${ }^{19}$

The start-up dummy is significant at $10 \%$ in the business survival equations, in line with Bates (1990), who argues that start-ups are less likely to survive compared to takeovers. Conversely, Oberschachtsiek (2012) finds that the takeover dummy has no effect on business closure. Importantly, our data set contains a

\footnotetext{
${ }^{19}$ These public partners generally also provide business development services, explaining the high correlation we observe between the provision of business development services and our "other debts" variable. As the effects of business development services on our dependent variables are less significant than the ones of "other debt," the latter variable seems to be a better control.
} 
Table 4 Pearson correlation coefficient for Repaying and Closed dummies

\begin{tabular}{lll}
\hline Full sample & Necessity entrepreneurs & Opportunity entrepreneurs \\
\hline-0.31 & -0.35 & -0.23 \\
\hline
\end{tabular}

large proportion of start-up businesses, which are also the main target of the microcredit.

The trade and food and accommodation sector dummies have a negative impact on business survival and no impact on loan repayment (the reference category is "other sectors" which include construction, arts and entertainment among others). The limited liability company dummy has no impact in either equation. Results on business cycles are available from the authors upon request.

Finally, $\rho$ corresponding to the correlation between the error terms in Eqs. 1 and 2 is only significant for loan repayment estimation. We conclude that using a bivariate probit model where the Necessity dummy is endogeneous is appropriate for loan repayment, as opposed to a simple probit equation.

Overall, we conclude that our findings are in line with the existing literature and support hypotheses 1 and 2. Necessity entrepreneurs have significantly more difficulty repaying their loans, corroborating previous studies reporting smaller and less profitable projects and Hypothesis 1. However, their businesses are just as likely to survive, because opportunity entrepreneurs tend to seize better external opportunities, despite higher intrinsic benefits from running a business, in line with Hypothesis 2.

To better understand the link between loan repayment and business closure, we provide in Table 4 the Pearson correlation coefficients for the full sample and for each entrepreneurial typology. As expected, the two dummies are negatively and significantly correlated (at 1\%). Interestingly, the correlation is higher (in absolute terms) for necessity entrepreneurs than for opportunity entrepreneurs $(-0.35$ versus -0.23 , respectively). These results are in line with our theoretical arguments according to which opportunity entrepreneurs are more likely to reimburse their loans despite business closure, due to better external opportunities.

We test our third hypothesis by overlooking the initial phase of the loans, when differences in business preparation are more likely to play a role. More specifically, we re-estimate the model on subsamples that exclude the observations with at least three late payments $m$ months after loan disbursement. We take different values of $m$, ranging from 3 to 24 months

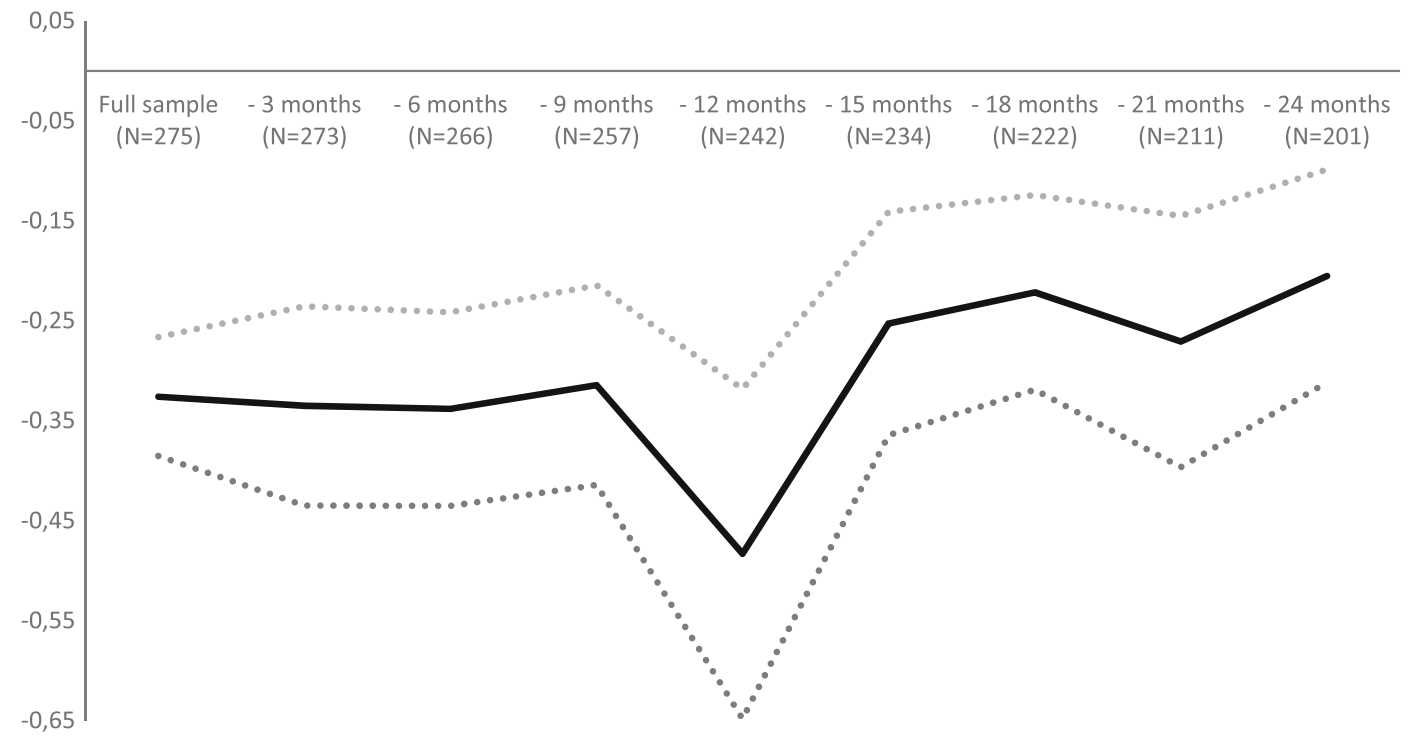

- Average Partial Effect of NE on Repayment $\quad \ldots .95 \% \mathrm{Cl}$

Fig. 1 Average partial effects of necessity motivation on loan repayment 
after loan disbursement. ${ }^{20}$ The average partial effects of the necessity entrepreneurship dummy (for the specification in column (2) in Table 3) are presented in Fig. 1.

We find large average partial effects, ranging from $-48 \%$ when we ignore all observations with at least three late payments during the first year after loan disbursement, ${ }^{21}$ to $-21 \%$ when we ignore all observations with at least three late payments during the first two years after loan disbursement. ${ }^{22}$ The effect of Necessity on loan reimbursement persists in time, as average partial effects are negative for all subsamples. Since these effects are not monotonously decreasing (in absolute value), ${ }^{23}$ Hypothesis 3 is not supported by our regression results. Therefore, the disparities between opportunity and necessity entrepreneurs do not seem to be mainly driven by differences in business project preparation.

\section{Alternative measure of entrepreneurial performance: duration models}

As the literature on credit scoring models (Roszbach 2004) indicates, it is not just credit default itself that is important, but when the default occurs. An early default is more costly for the bank than a default occurring towards the end of the loan period. The survival time of businesses too is now commonly analyzed in the literature on entrepreneurship (Oberschachtsiek 2012). Therefore, to refine our results we perform a duration analysis on loan repayment and business survival. However, in this alternative approach, we are no longer able to deal with the endogeneity of the Necessity dummy, since instrumental variable methods are not advanced enough for regression analysis of survival time with censoring (Tchetgen Tchetgen et al. 2015).

\footnotetext{
${ }^{20}$ After 24 months, the sample size becomes too small to trigger robust results.

${ }^{21}$ This means that the likelihood to experience repayment problems was 0.48 higher for necessity entrepreneurs than for opportunity entrepreneurs in the subsample in which we delete all the observation with at least three late payments during the first year after credit disbursement.

${ }^{22}$ The drop at $m=12$ corresponds to the subsample in which we drop the the highest number of observations.

${ }^{23}$ The $95 \%$ confidence interval does not show significant difference between coefficients.
}

To get around this, we adopt an alternative approach using a different definition of entrepreneurship motivation. Instead of using the variable Necessity, we directly include the variable Avoid_unemployment to proxy (the absence of) external opportunities. This alternative variable identifies respondents with push motives, who become self-employed to avoid unemployment. The main advantage of this approach is that it is relatively objective compared to the previous measure. Furthermore, this variable is less likely to be plagued with endogeneity. Finally, the number of observations used increases from 276 to 293 due to this change in the definition of entrepreneurial motivation.

This refinement allows us to go beyond the opportunity-necessity dichotomy by using a sharper definition of entrepreneurial motivation. We complete the analysis of the "avoid unemployment" motive by focusing on borrowers who declare starting a business "to fulfill a life project or dream." This motive relates closely to our theoretical mechanism based on non-pecuniary benefits. We thus alternatively use the Fulfill_dream dummy (see definition in Table 1) in place of Avoid_unemployment in the duration models.

\subsection{Estimation of survival time}

In Fig. 2, we give the survivor function $S(t)$ and the hazard function $h(t)$, where $t$ represents the time before the third late payment in the upper panel and the time before business closure in the lower panel. For censored observations (borrowers with strictly less than three late payments in their credit history and operating businesses), $t$ is the observation period. The survivor function is the probability of surviving beyond time $t$ and the hazard function is the probability of the failure event occurring within a given time interval, provided that the subject has survived until the beginning of that interval, divided by the width of the interval (Cleves et al. 2010).

We tested for equality of the survivor functions across necessity and opportunity entrepreneurs using a log-rank test (see Cleves et al. 2010, pp. 122124 for more details). We find a significant (at 10\%) difference between the survivor functions for time before three late payments in the credit history according to borrower motivation. However, no significant difference is detected for business survival time. 

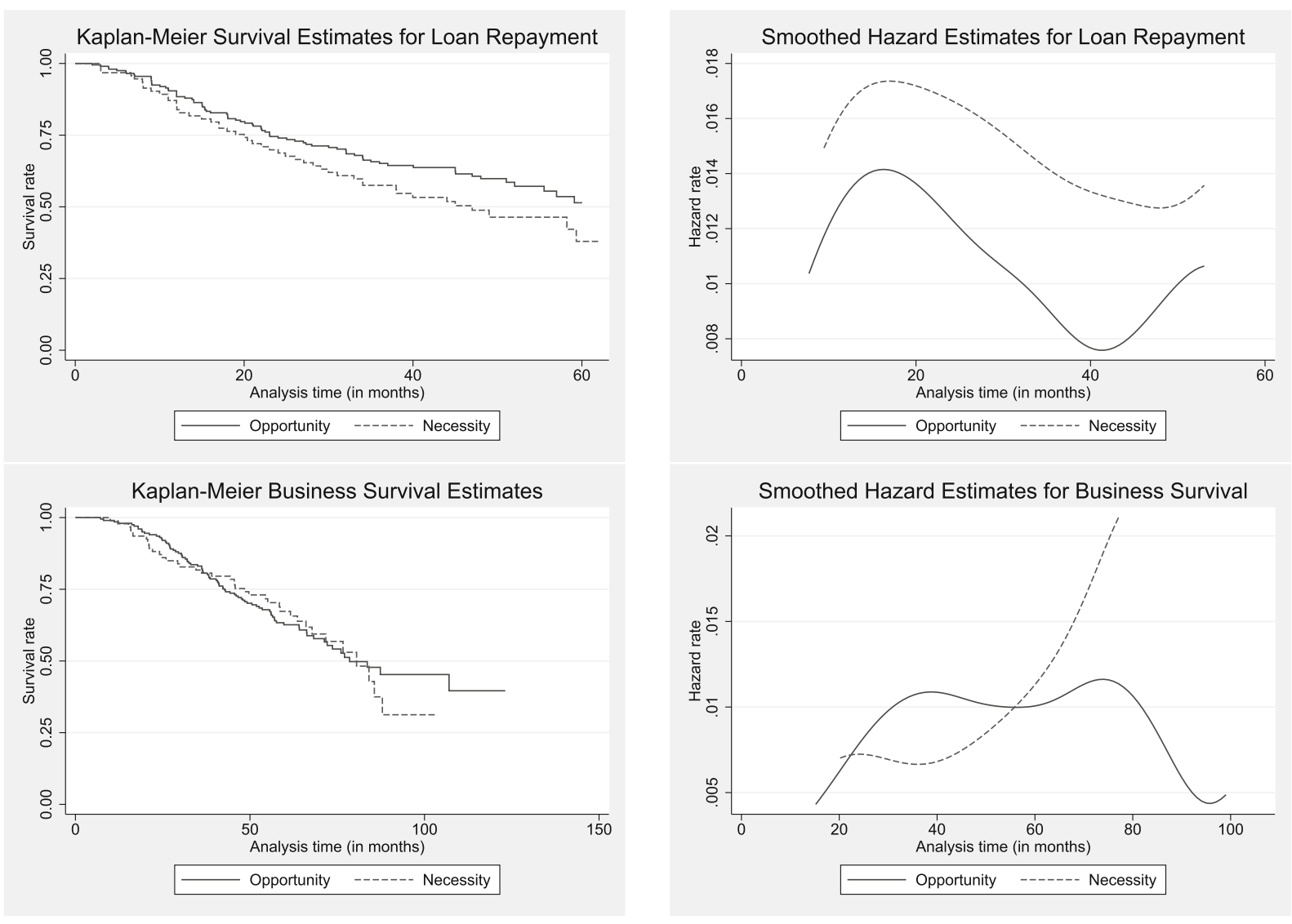

Fig. 2 Survivor and hazard functions

We use parametric duration models in accelerated failure-time (AFT) metric. ${ }^{24}$ Business survival analysis is close to Oberschachtsiek (2012), who also uses parametric AFT models for exits from selfemployment for initially unemployed individuals. In such models, a parametric distribution is assumed for the expected duration $\tau_{i}$, which is a function of the survival time $t_{i}$ and a vector of explanatory variables $\boldsymbol{x}$, which includes the Avoid_unemployment dummy, our main variable of interest:

$\tau_{i}=\exp \left(-\boldsymbol{x}_{\boldsymbol{i}} \boldsymbol{\beta}\right) t_{i}$

Therefore, the estimated models take the following form:

$\ln \left(t_{i}\right)=\boldsymbol{x}_{\boldsymbol{i}} \boldsymbol{\beta}+\ln \left(\tau_{i}\right)$

\footnotetext{
${ }^{24}$ We additionally use the Cox proportional hazards model (Cox 1992), which is a semi-parametric model, since the proportionality assumption cannot be rejected in our data (Schoenfeld 1981). This model yields similar results. They are available from the authors upon request.
}

where $\ln \left(\tau_{i}\right)$ has a distribution determined by what is assumed about the distribution of $\tau_{i}$ (Cleves et al. 2010) and vector $\boldsymbol{\beta}$ contains the parameters to be estimated. We tested different specifications for the distribution of $\tau_{i}$ (exponential, Weibull, lognormal, and log-logistic). According to the Akaike Information Criterion (AIC) and Bayesian Information Criterion (BIC), the best distribution according to the underlying data is the lognormal distribution where:

$\tau_{i} \sim \operatorname{lognormal}\left(\beta_{0}, \sigma\right)$

One salient feature of the lognormal distribution is that the hazard function is non-monotonic in time. It is first increasing and then decreasing. This feature is particularly relevant for our data, as illustrated in Fig. 2, for the hazard rate function, which seems to follow a non-monotonic pattern. Nevertheless, we additionally report the results for Weibull distribution $\left(\tau_{i} \sim\right.$ $\operatorname{Weibull}\left(\beta_{0}, p\right)$ ), since it allows for a monotonic hazard function, which also seems to be supported by the 
Table 5 Alternative measure of entrepreneurial performance: duration models with Avoid_Unemployment explanatory variable

\begin{tabular}{|c|c|c|c|c|c|c|c|c|}
\hline \multirow{3}{*}{$\begin{array}{l}\text { Estimation method: } \\
\text { Dependent variables: }\end{array}$} & \multicolumn{8}{|c|}{ Parametric duration models } \\
\hline & \multicolumn{4}{|c|}{ Time to 3rd late payment } & \multicolumn{4}{|c|}{ Time to business closure } \\
\hline & $\begin{array}{l}\text { Weibull } \\
\text { (1) }\end{array}$ & & $\begin{array}{l}\text { Lognormal } \\
\text { (2) }\end{array}$ & & $\begin{array}{l}\text { Weibull } \\
\text { (3) }\end{array}$ & & $\begin{array}{l}\text { Lognormal } \\
\text { (4) }\end{array}$ & \\
\hline \multicolumn{9}{|l|}{ Explanatory variables: } \\
\hline Avoid unemployment & $-0.28 *$ & $(0.16)$ & $-0.30 *$ & $(0.18)$ & 0.02 & $(0.14)$ & 0.02 & $(0.13)$ \\
\hline Age & $0.19 * * *$ & $(0.06)$ & $0.16^{* *}$ & $(0.07)$ & -0.06 & $(0.06)$ & -0.02 & $(0.06)$ \\
\hline $\mathrm{Age}^{2}$ & $-0.002 * * *$ & $(0.001)$ & $-0.002 * *$ & $(0.001)$ & 0.00 & $(0.00)$ & 0.00 & $(0.00)$ \\
\hline Male & -0.20 & $(0.17)$ & -0.25 & $(0.19)$ & 0.15 & $(0.14)$ & 0.17 & $(0.13)$ \\
\hline Education & 0.09 & $(0.08)$ & $0.16^{*}$ & $(0.09)$ & $0.13^{*}$ & $(0.07)$ & 0.11 & $(0.07)$ \\
\hline $\mathrm{HH}$ income & 0.07 & $(0.07)$ & 0.08 & $(0.07)$ & -0.05 & $(0.06)$ & -0.04 & $(0.06)$ \\
\hline Unemployed more 6 & -0.01 & $(0.16)$ & -0.07 & $(0.17)$ & -0.21 & $(0.13)$ & -0.21 & $(0.13)$ \\
\hline Project size & -0.00 & $(0.00)$ & -0.00 & $(0.00)$ & 0.00 & $(0.00)$ & 0.00 & $(0.00)$ \\
\hline Personal investment & 0.35 & $(0.22)$ & $0.60 * *$ & $(0.25)$ & 0.17 & $(0.18)$ & 0.10 & $(0.18)$ \\
\hline Other debts & $0.38 * *$ & $(0.17)$ & $0.33 *$ & $(0.18)$ & 0.05 & $(0.14)$ & 0.17 & $(0.13)$ \\
\hline Start-up & $-0.41 *$ & $(0.23)$ & -0.36 & $(0.23)$ & $-0.34 *$ & $(0.18)$ & $-0.43 * *$ & $(0.18)$ \\
\hline Trade & -0.08 & $(0.18)$ & -0.06 & $(0.21)$ & $-0.50 * * *$ & $(0.15)$ & $-0.56^{* * *}$ & $(0.15)$ \\
\hline Services & 0.24 & $(0.24)$ & 0.35 & $(0.26)$ & 0.10 & $(0.20)$ & 0.06 & $(0.19)$ \\
\hline Food and accommodation & -0.38 & $(0.26)$ & -0.28 & $(0.29)$ & $-0.55 * * *$ & $(0.21)$ & $-0.63 * * *$ & $(0.21)$ \\
\hline LLC & 0.05 & $(0.18)$ & 0.04 & $(0.19)$ & 0.01 & $(0.14)$ & 0.09 & $(0.14)$ \\
\hline Unemployment rate & -0.00 & $(0.03)$ & 0.01 & $(0.03)$ & 0.01 & $(0.03)$ & 0.01 & $(0.03)$ \\
\hline $\ln (\mathrm{p})$ & $0.23 * * *$ & $(0.08)$ & & & $0.45^{* * *}$ & $(0.07)$ & & \\
\hline $\ln (\sigma)$ & & & $0.14 * *$ & $(0.07)$ & & & $-0.17 * *$ & $(0.07)$ \\
\hline Constant & $3.74 * * *$ & $(1.30)$ & $3.37 * *$ & $(1.45)$ & $8.72 * * *$ & $(1.21)$ & $7.87 * * *$ & $(1.12)$ \\
\hline Business cycles & Yes & & Yes & & Yes & & Yes & \\
\hline Observations & 292 & & 292 & & 292 & & 292 & \\
\hline $\mathrm{Nb}$. of failures & 126 & & 126 & & 124 & & 124 & \\
\hline
\end{tabular}

Standard errors in parentheses

$* * * p<0.01, * * p<0.05, * p<0.1$

hazard function for necessity entrepreneurs in terms of business survival (see Fig. 2 the lower right graph).

The parameters $\beta$ presented in Table 5 illustrate the relationship between the explanatory variable and the survival time: a positive coefficient means that the higher the explanatory variable, the longer before a third late repayment (columns (1) and (2)) or business closure (columns (3) and (4)). Alternatively, the results can be interpreted in terms of time ratios, so that for an explanatory variable $x_{j}, \exp \left(\beta_{j}\right)$ is the factor by which the expected time-to-failure is multiplied as a result of a one-unit increase in $x_{j}$ (see Cleves et al. 2010, pp. 240-241 for more details).
Table 6 presents the same set of results for the duration models in which motivation is represented by the Fulfill_dream dummy instead of Avoid_unemployment dummy.

\subsection{Results}

In terms of duration models, we find that respondents who gave an Avoid_unemployment reason for business start-up have a 0.74 times shorter expected time before third late payment $(\beta=-0.3, \exp (\beta)=$ 0.74 ) than those who did not give this reason, according to the lognormal model. However, the length of 
Table 6 Alternative measure of entrepreneurial performance: duration models with Fulfill_Dream explanatory variable

\begin{tabular}{|c|c|c|c|c|c|c|c|c|}
\hline \multirow{3}{*}{$\begin{array}{l}\text { Estimation method: } \\
\text { Dependent variables: }\end{array}$} & \multicolumn{8}{|c|}{ Parametric duration models } \\
\hline & \multicolumn{4}{|c|}{ Time to 3rd late payment } & \multicolumn{4}{|c|}{ Time to business closure } \\
\hline & $\begin{array}{l}\text { Weibull } \\
\text { (1) }\end{array}$ & & $\begin{array}{l}\text { Lognormal } \\
\text { (2) }\end{array}$ & & $\begin{array}{l}\text { Weibull } \\
\text { (3) }\end{array}$ & & $\begin{array}{l}\text { Lognormal } \\
\text { (4) }\end{array}$ & \\
\hline \multicolumn{9}{|l|}{ Explanatory variables: } \\
\hline Fulfill a dream & $0.37 * *$ & $(0.16)$ & $0.44 * *$ & $(0.17)$ & 0.01 & $(0.13)$ & 0.05 & $(0.13)$ \\
\hline Age & $0.19 * * *$ & $(0.06)$ & $0.17 * *$ & $(0.07)$ & -0.06 & $(0.06)$ & -0.02 & $(0.06)$ \\
\hline $\mathrm{Age}^{2}$ & $-0.002 * * *$ & $(0.001)$ & $-0.002 * *$ & $(0.001)$ & 0.00 & $(0.00)$ & 0.00 & $(0.00)$ \\
\hline Male & -0.18 & $(0.17)$ & -0.19 & $(0.19)$ & 0.15 & $(0.14)$ & 0.18 & $(0.13)$ \\
\hline Education & 0.06 & $(0.08)$ & 0.14 & $(0.09)$ & $0.13 *$ & $(0.07)$ & 0.11 & $(0.07)$ \\
\hline $\mathrm{HH}$ income & 0.07 & $(0.07)$ & 0.05 & $(0.07)$ & -0.05 & $(0.06)$ & -0.04 & $(0.06)$ \\
\hline Unemployed more 6 & -0.04 & $(0.16)$ & -0.07 & $(0.17)$ & -0.20 & $(0.13)$ & -0.20 & $(0.13)$ \\
\hline Project size & -0.00 & $(0.00)$ & -0.00 & $(0.00)$ & 0.00 & $(0.00)$ & 0.00 & $(0.00)$ \\
\hline Personal investment & 0.36 & $(0.22)$ & $0.58 * *$ & $(0.24)$ & 0.17 & $(0.18)$ & 0.10 & $(0.18)$ \\
\hline Other debts & $0.32 *$ & $(0.17)$ & $0.30 *$ & $(0.18)$ & 0.05 & $(0.14)$ & 0.17 & $(0.13)$ \\
\hline Start-up & $-0.44^{*}$ & $(0.23)$ & $-0.39 *$ & $(0.23)$ & $-0.35^{* *}$ & $(0.17)$ & $-0.44 * *$ & $(0.17)$ \\
\hline Trade & -0.11 & $(0.18)$ & -0.08 & $(0.20)$ & $-0.50 * * *$ & $(0.15)$ & $-0.56^{* * *}$ & $(0.15)$ \\
\hline Services & 0.16 & $(0.24)$ & 0.30 & $(0.26)$ & 0.10 & $(0.20)$ & 0.06 & $(0.19)$ \\
\hline Food and accommodation & $-0.43^{*}$ & $(0.26)$ & -0.32 & $(0.29)$ & $-0.56 * * *$ & $(0.21)$ & $-0.63 * * *$ & $(0.21)$ \\
\hline LLC & 0.03 & $(0.18)$ & 0.05 & $(0.19)$ & 0.01 & $(0.14)$ & 0.09 & $(0.14)$ \\
\hline Unemployment rate & 0.00 & $(0.03)$ & 0.01 & $(0.03)$ & 0.01 & $(0.03)$ & 0.01 & $(0.03)$ \\
\hline $\ln (\mathrm{p})$ & $0.24 * * *$ & $(0.08)$ & & & $0.45^{* * *} *$ & $(0.07)$ & & \\
\hline $\ln (\sigma)$ & & & $0.14^{*}$ & $(0.07)$ & & & $-0.17 * *$ & $(0.07)$ \\
\hline Constant & $3.58 * * *$ & (1.27) & $3.10 * *$ & $(1.44)$ & $8.74 * * *$ & $(1.21)$ & $7.87 * * *$ & $(1.11)$ \\
\hline \multicolumn{9}{|l|}{ Business cycles } \\
\hline Observations & 292 & & 292 & & 292 & & 292 & \\
\hline $\mathrm{Nb}$. of failures & 126 & & 126 & & 124 & & 124 & \\
\hline
\end{tabular}

Standard errors in parentheses

$* * * p<0.01, * * p<0.05, * p<0.1$

business survival is not significantly different across the two groups. This latter result challenges Oberschachtsiek (2012)'s finding of a positive relationship between "pull" motivation (corresponding to opportunity entrepreneurs) and business survival. Overall, the results for the duration model corroborate our previous findings using bivariate probit models and therefore hypotheses 1 and 2 . Necessity entrepreneurs seem to experience significantly more difficulties with loan repayment, and these difficulties arise earlier. Yet, they do not seem to close their businesses more often or earlier than opportunity entrepreneurs.

A few results concerning other controls are worth mentioning. One difference from Table 3 consists in the significant coefficient for education in the lognormal specification for late repayment, suggesting that a higher level of education increases the time before third late repayment. The personal investment dummy also positively impacts the survival in this specification. The "start-up" dummy is associated with a 
Table 7 Cost-benefit analysis

\begin{tabular}{|c|c|c|}
\hline & Opportunity entrepreneurs & Necessity entrepreneurs \\
\hline \multicolumn{3}{|l|}{ Predicted risk } \\
\hline $\begin{array}{l}\text { Probability of having } \geq 3 \text { late payments in the credit history } \\
\text { (probability of default) }\end{array}$ & 0.27 & 0.60 \\
\hline $\begin{array}{l}\text { Expected survival time before } 3 \text { rd late payment } \\
\text { (nb. of months before default) }\end{array}$ & 23 & 17 \\
\hline \multicolumn{3}{|l|}{ Loan characteristics } \\
\hline Average loan size (EUR) & 8250 & 8250 \\
\hline Average interest rate & $4.4 \%$ & $4.4 \%$ \\
\hline Average loan duration (months) & 52 & 52 \\
\hline \multicolumn{3}{|l|}{ Returns } \\
\hline Capital return for fully repaid loans (EUR) & 8250 & 8250 \\
\hline Interest return for fully repaid loans (EUR) & 827 & 827 \\
\hline Capital return before 3rd late payment (EUR) & 3456 & 2526 \\
\hline Interest return before 3rd late payment (EUR) & 558 & 441 \\
\hline Expected capital return (EUR) & 6935 & 4814 \\
\hline Expected interest return (EUR) & 753 & 595 \\
\hline Expected gross capital loss (EURs) & 1315 & 3436 \\
\hline Expected guarantee ( $70 \%$ of gross capital loss) (EUR) & 921 & 2405 \\
\hline Expected net capital loss (EUR) & 395 & 1031 \\
\hline
\end{tabular}

shorter time to third late payment in the Weibull specification, whereas it was not significant in the first two columns of Table 3. Other debts have no significant impact on business survival, in contrast to the results in Table 3.

Finally, we note that the Weibull shape parameter is significant at $1 \%$ level, with $\ln (p)>0$, meaning that $p>1$ and the Weibull hazard is monotone increasing in time. $\sigma$, which is the lognormal distribution parameter, is also significantly different from zero at $5 \%$ level, suggesting the presence of a nonmonotonic hazard function.

Hypotheses 1 and 2 are also supported by our durations analysis with the Fulfill_dream dummy (see Table 6). We find a positive effect (significant at 5\%) of this dummy on the time before third late payment, supporting Hypothesis 1. In line with our previous findings and Hypothesis 2, no impact on business survival is detected. The loadings for other control variables are robust to this alternative approach which allows taking into account the multi-dimensional character of entrepreneurial motivation.

\section{Policy implications}

In the context of highly subsidized microcredit, it seems crucial to assess the size of the portfolio subsidy and compare it to the welfare savings over the loan period. In this section, we provide a computation of expected returns for each type of entrepreneur and analyze whether public intervention (through loan guarantee) justifies the tax payers exposure to the microcredit market. ${ }^{25}$ Using the results of Tables 3 and 5, we predict the expected probability of having at least three late payments and the survival time before the third late payment for each type of entrepreneur. We adopt a conservative (and simplifying) approach, assuming that three late payments in the credit history are equivalent to loan default. The different elements for this computation are presented in Table 7 .

The predicted probability of having at least three unpaid installments is equal to 0.27 for opportunity

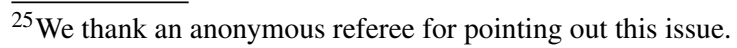


entrepreneurs. Using the average partial effect presented in Fig. 1 for the full sample, this probability increases to 0.6 for necessity entrepreneurs. ${ }^{26}$

The average survival time for opportunity entrepreneurs before the third late payment is equal to 23 months in our data set. Using the results of Table 5 column (2) (lognormal specification), we expect the survival time for necessity entrepreneurs to be 0.74 times shorter, that is 17 months.

Loan characteristics do not vary significantly with respect to entrepreneurial typologies. We therefore use the average values for both types of entrepreneurs. We assume an average loan size of EUR 8250, at a fixed interest rate of $4.4 \%$ for a period of 52 months.

This allows us to compute the capital and interest return using a decreasing balance amortization schedule for a loan with the above characteristics. A borrower who stops repaying 23 months after loan disbursement reimburses EUR 3456 of capital; against EUR 2526 for a borrower who stops repaying after 17 months. Interest returns before third late payment are computed in a similar way (see Table 7).

The MFI providing data receives $70 \%$ of the capital loss through a publicly subsidized program. It thus ends up with an expected net (after guarantee) capital loss of EUR 395 for opportunity entrepreneurs and EUR 1031 for necessity entrepreneurs.

We note that these net losses are almost entirely covered by the expected interest returns. Since the expected interest return is higher than the expected net capital loss for opportunity entrepreneurs, Table 7 provides evidence for cross-subsidization (Armendáriz and Szafarz 2011) where positive returns generated by opportunity entrepreneurs can be used to compensate for losses generated by necessity entrepreneurs.

We can now compare the expected size of the subsidy with the welfare benefits saved over the loan period. According to the French employment agency, unemployed individuals receive on average a monthly allowance equal to EUR 1160 during a period of 13 months (De Visme 2016; Delvaux 2016). Obviously, accounting only for the costs of

\footnotetext{
${ }^{26}$ These probabilities of default appear particularly large, especially for the microfinance industry where MFIs generally boast very high repayment rates (Armendáriz and Morduch 2010). However, they are generated by our conservative approach assuming that all the borrowers experiencing repayment problems will actually not repay their loan. It is worth reminding that in our sample $43 \%$ of individuals had at least three unpaid installments in their credit history.
}

default, subsidization of both opportunity and necessity entrepreneurs makes perfect sense (according to Table 7 the expected cost of loan guarantee amounts respectively to EUR 921 and EUR 2405).

In this analysis, we focus exclusively on the cost of risk, neglecting other costs (such as financial and operating costs) key to MFIs. Accounting for these additional costs (which obviously do not vary with respect to the type of entrepreneurial motivation) would provide a more realistic estimation of the costs per borrower incurred by MFIs. ${ }^{27}$

MFIs receive many subsidies on top of loan guarantee. These can take the form of direct subsidies, soft loans from public institutions or commercial banks, subsidization of business development services which are generally provided by external entities or volunteers (Botti et al. 2016), etc. The subsidization of business development services (and other types on non-financial services) is particularly important, since they can be designed according to entrepreneurial typologies. A more rigorous cost benefit analysis for MFIs in Europe (taking into account all the aspects discussed above) is crucial for the promotion and the development of the industry and should be a priority for further research. Still, our results suggest that the difference in expected costs of loan guarantee between opportunity and necessity entrepreneurs represent less than 1.5 months of unemployment allowance.

\section{Conclusion}

This article analyzes the link between entrepreneurial motivation and business performance. Our contribution to the extant literature is twofold. First, we analyze entrepreneurial motivation in a particular context: French microfinance. We find that, in our sample, almost $52 \%$ of micro-entrepreneurs are necessity entrepreneurs. This feature of our data set makes the analysis of entrepreneurial motivation particularly relevant, since we have a relatively heterogeneous data set compared to previous studies (Block and Sandner 2009). Such heterogeneity is not surprising, given that microfinance in Europe is a policy

\footnotetext{
${ }^{27}$ According to Brabant et al. (2007), the operating cost per borrower (including the application analysis, credit disbursement and follow-up but excluding non-financial services) varies between EUR 735 and EUR 500 per year for licensed MFIs in France.
} 
tool encouraging self-employment as a way out of unemployment (Bendig et al. 2012). In line with this definition, target microfinance clients are expected to be necessity entrepreneurs. That said, microfinance also plays a more general role, serving the rejected applicants of mainstream banks. Start-ups whose founders have limited personal asset to invest are typically rejected by the mainstream financial market due to lack of credit history or of sufficient levels of collateral. Therefore, rejected opportunity micro-entrepreneurs are just as likely to apply for a microcredit. Importantly, Duflo (2010) argues that differentiating between entrepreneurial motivation is one of the major challenges for the microfinance sector.

Second, using a hand-collected data set from a French MFI, containing detailed individual information on credit history, we exploit a novel indirect measure of business performance, namely loan repayment. Its advantage over previous performance measures such as employment and turnover growth relies on the argument that not all entrepreneurs wish to grow (Jaouen and Lasch 2015). Following this argument, we interpret difficulty in loan repayment as an indirect way to measure poor business performance, getting around the limitation of voluntary unwillingness to grow. We find that necessity entrepreneurs have significantly more difficulty repaying their loans. This effect persists in time, suggesting that it is not exclusively due to the potential lack of preparation of the business project by necessity entrepreneurs.

In parallel, we perform a business survival analysis, which is particularly relevant since there is still no consensus on the relationship between entrepreneurial motivation and business survival. Our paper finds a non-significant relationship between necessity motivation and business survival, challenging the recent finding by Oberschachtsiek (2012) of a negative relationship. Our theoretical framework, according to which opportunity entrepreneurs enjoy both higher external opportunities and larger non-pecuniary benefits from success, provides formal arguments supporting this non-significant relationship. Our findings are robust to a multi-dimensional assessment of entrepreneurial typologies.

In terms of policy implications, the literature suggests that having received a start-up subsidy decreases the risk of exiting self-employment (Millán et al. 2012). In France, the microfinance sector benefits from strong government support in the form of direct or indirect subsidies (Bendig et al. 2014). Our paper shows that necessity entrepreneurs are just as likely as opportunity entrepreneurs to stay in business. Using a simple cost-benefit computation, we moreover show that most of the net expected capital losses can be covered by expected interest returns and that the expected cost of loan guarantee is low compared to the welfare savings. From this perspective, the microfinance sector, where necessity micro-entrepreneurs are overrepresented, is worth subsidizing. However, our results additionally show that despite equal chances of surviving, necessity micro-entrepreneurs struggle to face their financial commitments, most likely due to the limited growth potential of their businesses (Jaouen and Lasch 2015). The regulator should be aware of this caveat when designing programs targeting necessity entrepreneurs. One way of tackling this problem is by subsidizing business development services (Bourlès and Cozarenco 2014) which can be designed according to entrepreneurial motivation.

Owners of businesses that close might continue to be self-employed in some other firm or become paid employees, unemployed or inactive (Millán et al. 2012). Using a competing risk model, we could identify any potential difference in exit state between opportunity and necessity entrepreneurs. One of the limitations of our data set is the fact that we do not observe the exit state when there is business closure. If necessity entrepreneurs are just as likely as opportunity entrepreneurs to switch to paid employment, subsidizing business start-ups through microfinance makes perfect sense. Further research would be useful to explore whether professional experience (human capital) acquired through self-employment or the business development services provided by most European MFIs can lead to a stable wage-earning position in the future.

Another limitation is that we observe entrepreneurial motivation at the time of the survey, which coincides with different stages in the respondents' business life-cycle. This is problematic, since entrepreneurs are subject to dynamic motivations (Jayawarna et al. 2013). To get around this, we use an alternative measure of entrepreneurial motivation in the robustness checks. A more rigorous way to deal with this limitation would be to administer the survey at the time of loan application. This procedure would also help control for selection bias (Heckman 1979) by using data on rejected applicants from the MFI. 
Finally, survival models using the instrumental variable technique could be implemented to control for the endogeneity of entrepreneurial motivation. One step in this direction is provided by Tchetgen Tchetgen et al. (2015). However, the technique is still in development phase and would need adapting.

Acknowledgements The authors would like to thank Mohamed Belhaj, Olivier Chanel, Dominique Henriet, Xavier Joutard, Frank Lasch, Bernard Sinclair-Desgagné, Roy Thurik, and Peter van der Zwan for useful comments and discussions; and Marjorie Sweetko for English language revision. The authors are grateful to Colette Grunenberger for research assistance.

Funding information Anastasia Cozarenco benefited from LabEx "Entrepreneurship" (University of Montpellier, France) funding. This "laboratory of excellence" is funded by the French government in recognition of high-level research initiatives in the human and natural sciences.

\section{References}

Acs, Z., \& Varga, A. (2005). Entrepreneurship, agglomeration and technological change. Small Business Economics, 24(3), 323-334.

Andersson, J.P., \& Wadensjo, E. (2007). Do the unemployed become successful entrepreneurs? A comparison between unemployed, inactive and wage-earners. International Journal of Manpower, 28(7), 604-626.

Armendáriz, B., \& Morduch, J. (2000). Microfinance beyond group lending. Economics of Transition, 8(2), 401-420.

Armendáriz, B., \& Morduch, J. (2010). The economics of microfinance (2nd edn.) Cambridge: MIT Press.

Armendáriz, B., \& Szafarz, A. (2011). On mission drift in microfinance institutions. In B. Armendáriz, \& M. Labie (Eds.) The handbook of microfinance (pp. 341-366). Singapore: World Scientific.

Audretsch, D.B., \& Thurik, A.R. (2001). What's new about the new economy? Sources of growth in the managed and entrepreneurial economies. Industrial and Corporate Change, 10(1), 267-315.

Banerjee, A., Karlan, D., Zinman, J. (2015). Six randomized evaluations of microcredit: introduction and further steps. American Economic Journal: Applied Economics, 7(1), 121.

Bates, T. (1990). Entrepreneur human capital inputs and small business longevity. Review of Economics and Statistics, 72(4), 551-559.

Benabou, R., \& Tirole, J. (2003). Intrinsic and extrinsic motivation. Review of Economic Studies, 70(3), 489-520.

Bendig, M., Unterberg, M., Sarpong, B. (2012). Overview of the microcredit sector in the European Union 2010-2011. European Microfinance Network.

Bendig, M., Unterberg, M., Sarpong, B. (2014). Overview of the microcredit sector in the European Union 2012-2013. European Microfinance Network.
Benz, M., \& Frey, B.S. (2008). Being independent is a great thing: Subjective evaluations of self-employment and hierarchy. Economica, 75(298), 362-383.

Berger, A.N., \& Udell, G.F. (2002). Small business credit availability and relationship lending: the importance of bank organisational structure. Economic Journal, 112(477), F32F53.

Bergmann, H., \& Sternberg, R. (2007). The changing face of entrepreneurship in Germany. Small Business Economics, 28(2), 205-221.

Bhola, R., Verheul, I., Thurik, R., Grilo, I. (2006). Explaining engagement levels of opportunity and necessity entrepreneurs. EIM Business and Policy Research, H200610.

Blanchflower, D.G. (2000). Self-employment in OECD countries. Labour Economics, 7(5), 471-505.

Block, J., \& Sandner, P. (2009). Necessity and opportunity entrepreneurs and their duration in self-employment: evidence from German micro-data. Journal of Industry, Competition and Trade, 9(2), 117-137.

Block, J.H., \& Wagner, M. (2010). Necessity and opportunity entrepreneurs in Germany: characteristics and earnings differentials. Schmalenbach Business Review, 62, 154-174.

Block, J.H., Hoogerheide, L., Thurik, R. (2011). Education and entrepreneurial choice: an instrumental variables analysis. International Small Business Journal, 31(1), 23-33.

Block, J., Kohn, K., Miller, D., Ullrich, K. (2015). Necessity entrepreneurship and competitive strategy. Small Business Economics, 44(1), 37-54.

Botti, F., Dagradi, D.L., Torre, L.M. (2016). Microfinance in Europe: a survey of EMN-MFC members. European Microfinance Network Report 2014-2015.

Bourlès, R., \& Cozarenco, A. (2014). State intervention and the microcredit market: the role of business development services. Small Business Economics, 43(4), 931-944.

Bourlès, R., \& Cozarenco, A. (2017). Entrepreneurial motivation and business performance: evidence from a French micronance institution. AMSE working paper 2017-01.

Brabant, M., Dugos, P., Massou, F. (2007). Rapport sur le microcrédit. Inspection Générale des Finances.

Cleves, M.A., Gould, W.W., Gutierrez, R.G., Marchenko, Y. (2010). An introduction to survival analysis using stata. College Station: Stata Press.

Cox, D.R. (1992). Regression models and life-tables (with discussion). Journal of the Royal Statistical Society: Series B, $34,187-220$.

Cozarenco, A. (2015). Microfinance institutions and banks in Europe: the story to date. Working Papers CEB Nb. 15, Université Libre de Bruxelles.

Cozarenco, A., \& Szafarz, A. (2016). Microcredit in industrialized countries: unexpected consequences of regulatory loan ceilings. Working Papers CEB Nb. 16, Université Libre de Bruxelles.

Cozarenco, A., Hudon, M., Szafarz, A. (2016). What type of microfinance institutions supply savings products? Economics Letters, 140, 57-59.

Dalborg, C., \& Wincent, J. (2015). The idea is not enough: the role of self-efficacy in mediating the relationship between pull entrepreneurship and founder passion-a research note. International Small Business Journal, 33(8), 974984. 
De Visme, N. (2016). Poursuite de la baisse de l'ICDC au 1er trimestre 2016. Statistiques, Etudes et Evaluations de Pôle Emploi Nr. 16.022.

Delvaux, G. (2016). Montant de l'allocation chômage versée aux demandeurs d'emploi indemnisés par l'assurance chômage: Situation au 30 septembre 2015. Statistiques, Etudes et Evaluations de Pôle Emploi Nr. 16.028.

D’Espallier, B., Hudon, M., Szafarz, A. (2013). Unsubsidized microfinance institutions. Economics Letters, 120(2), 174176.

Duflo, E. (2010). Microcrédit, miracle ou désastre? Le Monde.

European Commission (2012). Report from the Commission to the European Parliament and the Council (on the application of Directive 2006/48/EC to Microcredit) Brussels, 18:12:2012.

Eurostat (2015). Statistiques structurelles sur les entreprises vue d'ensemble. Données de janvier 2015.

Gilad, B., \& Levine, P. (1986). A behavioral model of entrepreneurial supply. Journal of Small Business Management, 24(4), 45-54.

Hamilton, B.H. (2000). Does entrepreneurship pay? An empirical analysis of the returns to self-employment. Journal of Political Economy, 108(3), 604-631.

Heckman, J.J. (1979). Sample selection bias as a specification error. Econometrica, 47(1), 153-161.

Hudon, M., \& Traça, D. (2011). On the efficiency effects of subsidies in microfinance: an empirical inquiry. World Development, 39(6), 966-973.

Hundley, G. (2001). Why and when are the self-employed more satisfied with their work? Industrial Relations: A Journal of Economy and Society, 40(2), 293-316.

Jaouen, A., \& Lasch, F. (2015). A new typology of micro-firm owner-managers. International Small Business Journal, 33(4), 397-421.

Jayawarna, D., Rouse, J., Kitching, J. (2013). Entrepreneur motivations and life course. International Small Business Journal, 31(1), 34-56.

Jonsson, S., \& Lindbergh, J. (2013). The development of social capital and financing of entrepreneurial firms: From financial bootstrapping to bank funding. Entrepreneurship Theory and Practice, 37(4), 661-686.

Kariv, D., \& Coleman, S. (2015). Toward a theory of financial bricolage: the impact of small loans on new businesses. Journal of Small Business and Enterprise Development, 22(2), 196-224.

Kirkwood, J. (2009). Motivational factors in a push-pull theory of entrepreneurship. Gender in Management: An International Journal, 24(5), 346-364.

Korunka, C., Frank, H., Lueger, M., Mugler, J. (2003). The entrepreneurial personality in the context of resources, environment, and the startup process - a configurational approach. Entrepreneurship Theory and Practice, 28(1), 23-42.

Lange, T. (2012). Job satisfaction and self-employment: autonomy or personality? Small Business Economics, 38(2), 165177.
Millán, J.M., Congregado, E., Román, C. (2012). Determinants of self-employment survival in Europe. Small Business Economics, 38(2), 231-258.

Morduch, J. (1999). The role of subsidies in microfinance: evidence from the Grameen Bank. Journal of Development Economics, 60(1), 229-248.

Naudé, W. (2010). Entrepreneurship, developing countries, and development economics: new approaches and insights. Small Business Economics, 34(1), 1-12.

Newman, A., Schwarz, S., Borgia, D. (2014). How does microfinance enhance entrepreneurial outcomes in emerging economies? The mediating mechanisms of psychological and social capital. International Small Business Journal, 32(2), 158-179.

Oberschachtsiek, D. (2012). The experience of the founder and self-employment duration: a comparative advantage approach. Small Business Economics, 39(1), 1-17.

Reed, L., Marsden, J., Ortega, A., Rivera, C., Rogers, S. (2014). Resilience: the state of the microcredits summit campaign report. The Microcredit Summit Campaign.

Reynolds, P., Bosma, N., Autio, E., Hunt, S., De Bono, N., Servais, I., Lopez-Garcia, P., Chin, N. (2005). Global entrepreneurship monitor: data collection design and implementation 1998-2003. Small Business Economics, 24(3), 205-231.

Roszbach, K. (2004). Bank lending policy, credit scoring, and the survival of loans. Review of Economics and Statistics, 86(4), 946-958.

Schoenfeld, D. (1981). The asymptotic properties of nonparametric tests for comparing survival distributions. Biometrika, 68(1), 316-319.

Shahriar, A.Z.M., Schwarz, S., Newman, A. (2016). Profit orientation of microfinance institutions and provision of financial capital to business start-ups. International Small Business Journal, 34(4), 532-552.

Stephan, U., Hart, M., Mickiewicz, T., Drews, C.-C. (2015). Understanding motivations for entrepreneurship. BIS Research Paper 212.

Taylor, M.P. (1996). Earnings, independence or unemployment: why become self-employed? Oxford Bulletin of Economics and Statistics, 58(2), 253-266.

Tchetgen Tchetgen, E.J., Walter, S., Vansteelandt, S., Martinussen, T., Glymour, M. (2015). Instrumental variable estimation in a survival context. Epidemiology, 26(3), 402410.

Tirole, J. (2006). The theory of corporate finance. Princeton: Princeton University Press.

Wagner, J. (2005). Nascent necessity and opportunity entrepreneurs in Germany evidence from the Regional Entrepreneurship Monitor (REM). University of Lüneburg Working Paper Series in Economics Nr 10.

Wennekers, S., \& Thurik, R. (1999). Linking entrepreneurship and economic growth. Small Business Economics, 13(1), 27-56.

Wooldridge, J.M. (2010). Econometric analysis of cross section and panel data. Cambridge: MIT Press. 